\title{
THE RIGHTS OF PRIVATE ECONOMIC ACTORS UNDER THE WORLD TRADE ORGANIZATION AGREEMENTS IN INDONESIA
}

\author{
Intan Soeparna ${ }^{1}$
}

\begin{abstract}
Nothing in the Uruguay Round mentions directly about rights of private economic actors. It seems that the relationship to private economic actors (or may be individual) does not exist within the WTO Agreements, because as a general rule, private parties are not legal subjects of the international legal order. However, this article will prevail upon this situation, by looking closer at the essence of the WTO Agreements to discern the rights of private economic actors that derive from the WTO. The main question of this article is to what extent then Indonesia is dealing with the rights of private economic actors under the WTO Agreements? The background of this questionis because four years after ratifying the WTO Agreements, Indonesia has been facing what is arguably the most serious multidimensional crisis in 1997, some difficult situations have arisen from the crisis; therefore, the society hesitated to accept the open world trading system. The society seemed look askance to the implementation of the WTO Agreements. But Indonesian Government took major step to reduce the skepticism of society toward liberalization, by readjusting its national laws conform to the WTO Agreements with the intention to support the rights of national economic actors under the WTO Agreements in order to achieve total benefits of the WTO rules.
\end{abstract}

Keywords: the WTO Agreements, private economic actors, Indonesian Government

\section{Introduction}

The main reason for Indonesia to get involved in international trade is the sole concern of a total and beneficial participation in open global trading system for all Indonesian people. Nevertheless, this effort was presumably facing insurmountable dissenting voices from many levels of internal or external civil societies. Since Indonesia has been facing what is arguably the most serious multidimensional crisis in 1997, some difficult situations have arisen from the crisis, therefore, an open world trading system caused society

\footnotetext{
${ }^{1}$ Lecturer of International Law at Faculty of Law, Airlangga University, obtained Bachelor of Law from University of Padjadjaran (1999), Master of Humanities, Gadjah Mada University (2002), Research Staff at Private and Economic Law Centre (PREC), Faculty of Law and Criminology, Vrije Universiteit Brussel, and PhD Candidate at Vrije Universiteit Brussel (VUB) and Gent University (UGent) Belgium. This paper has been discussed in International Law: Trickle down Effect Symposium, 4-11 May 2011 at Edinburgh University UK.
} 
to hesitate in accepting it. The crisis began four years after ratification of the WTO Agreements, due to the lack of preparation in liberalization of financial sector. The early liberalization that Indonesian Government undertook was in the banking sector with respect to financial services in the Uruguay Round. The excessively rapid liberalization of Indonesia's banking and financial sectors, which were not accompanied by appropriate preparation of the regulatory institutions to enable them to supervise the expanded banking and financial institutions, led to poor governance in the banking system. In 1997, the banking system collapsed. It did so not because of foreign competition, but because of inadequate preparation. Unfortunately, whatever its root causes, it led to skepticism toward liberalization in general. ${ }^{2}$

The Government of Indonesia therefore made major step to reduce the skepticism of society toward liberalization by readjusting its national laws conform to the WTO Agreements with the intention to support national economic actors including Small and Medium Enterprises into benefits of the WTO rules. However, it was not an easy task to promulgate new national law accordance with the WTO rules; there was growing concern among those private economic actors and Indonesian society regarding the enforcement of national law in the WTO manner. Thus, the purpose of this article is to answer the issue in regard with to what extent is Indonesia dealing with the rights of private economic actors under the WTO Agreements?"

There are two reasons in accommodating the issue, first, Indonesia is obliged to comply with the WTO Agreements as a member, and second, Indonesian Government is duty bound to endorse private economic actors to participate in international trade arena in to benefits of the WTO Agreements. This article is divided in two main parts. First, the concept of private economic actors in the array of the WTO Agreements, to see the coherence factor between the concept of private economic actors in the WTO and their rights that derive from it and, second, to discuss to what extent Indonesia is dealing with this concept.

\section{The Private Economic Actors as Main Player of WTO Rules}

A private economic actor is defined as an individual acting as producer, seller, consumer, worker, investor, exporter and importer (in economic theory they are known as economic agents). In a general legal framework, the legal definition of economic actor has moved beyond a simple barter system to more global economic system. The basic legal definition of economic actor is a person (legal entity), who is holding the object of economic activity (proprietorship) which then becomes broader with the concept of partnership (joint ownership). ${ }^{3}$ But this general legal definition is of course established

${ }^{2}$ H.S. Kartadjoemena, (2005). 'Country Report: Indonesia', in The World Trade Organization: Legal, Economic and Political Analysis Volume I,Ed. By Patrick F.J. Macrory, Arthur E. Appleton and Michael G. Plumer, New York: Springer Science+Business Media Inc.,p. 137-70.

${ }^{3}$ See S.B. Marsh and J.Soulsby, (2002).Business Law: Eight Edition, UK: Nelson Thomas Ltd, p. 54. Legal entity is anything recognized by law as having legal right and duties, it is simply a person in the ordinary sense but the person who has legal capacity.

See also the ancient definition of proprietorship according to the Circuit Court of the United States for the Eastern District of Pennsylvania - In Equity, 'in the case of Laura Keene vs. Wheatley \& Clarke', col- 
by the ruling of government which mostly acts as an economic policy maker. Concerning the economic activity within a country, government is acting as economic regulator and policy maker. Economic regulation is an important instrument for government policies in the market economy system. ${ }^{4}$ Some forms of regulations are concerned with setting a framework of rules for people to follow in their dealing with each other. Such regulations apply to all market participants and are defended as a means of making the market process more efficient over the long term. ${ }^{5}$

In the globalization era, the economic activity of state is indispensable to international economic relations. Governments increasingly find it difficult to implement adequate policies regarding economic activity because such activity often crosses the borders in ways that escape the reach of much of national government control. ${ }^{6}$ Responding to these difficulties, states have created a number of international organizations with competences in the field of economic relations. Hence, states are embarking on their economy policies in harmony with international economic agreements, such as UN Treaty family of international economic relations. ${ }^{7}$ Even if nearly all of these international economic agreements lack a binding character, they influence national economic policies and thereby indirectly impinge upon private participants in international economic relations. ${ }^{8}$ From this point of view, there are two levels of subjects involved in international economic relations. First, an interstate or organization-state level covering the relationships among the traditional subjects of international law; and second, a level of nationals (individual or legal persons) belongs to different state. The interstate level deals with co-ordination of economic policies, elaboration of guidelines and the mechanism for international economic co-operation. Meanwhile, direct economic interactions on production and exchange of goods are executed at the national level by private economic actors. ${ }^{9}$ Accordingly, the state is directly applying interna-

lected by Asa I. Fish and Henry Wharton (eds), (1861).

The American Law Register Vol. IX, D.B. Canfield \& Co. Goldsmiths Hall, Library Street -US. p. 61. Proprietorship is a certain or contingent exclusive rights of unlimited or limited profitable use of an ascertainable subject, corporeal or incorporeal. Proprietorship thus is defined as compounded of the proprietor beneficial rights, and his rights of excluding other persons from the use or profit.

${ }^{4}$ In this context, author only implies the concept of private economic actors in the market economy country. Market economy country is economy based on the division of labour in which the prices of goods and services are determined in a free price system set by supply and demand. Indonesia constitutes as market economy country. See E. Altvater, (1993).The Future of the Market: An Essay on the Regulation of Money and Nature After the Collapse of Actually Existing Socialism, London: Verso press. p. 237-38.

${ }^{5}$ Martin Rickettss, (2006). "Economic Regulations: Principles, History and Methods", in International Handbook on Economic Regulation, Ed. By Michael Crew and David Parker, UK: Edward Elgar Publishing, p.34.

${ }^{6}$ John H. Jackson,(1997).The World Trading System: Law and Policy of International Economic Law (second Edition), Massachusetts: Massachusetts Institutes of Technology Press., p.1.

${ }^{7}$ See Philip Kunig, Niels Lau and Werner Meng,(1993).International Economic Law : Basic Documents, Berlin: Walter de Gruyter \& Co., p. 3-42. International Economic Law in this book is divided in to economic international and regional cooperation and regulation of the international economy. See also Andreas F. Lowenfeld, (2008). International Economic Law, Second Edition, in International Economic Law Series,UK: Oxford - University Press., p. 21-72.

${ }^{8}$ Philip Kunig, Niels Lau and Werner Meng, Ibid., Although lack of binding character, the international economic agreements are upheld to be law when state is voluntarily adopting them into its national legislation. Hence it is quiet evidence that international economic relations as a whole cannot be regulated in isolation by either international economic law or municipal law.

${ }^{9}$ See Sergei A. Voitovich, (1995).International Economic Organizations in the International Legal 
tional economic agreements which are concerned with regulating all market participants including non-state economic actors or private economic actors.

\section{A. Private Economic Actors in the International Economic Law Level}

The argument regarding the international economic law mostly began with the notion and good will of a state to conduct further cross border relation in economic field, such as monetary and financial issues, investment, transport and communication, industrial and agricultural and more ${ }^{10}$ However, the core of intensive international economic relation begins with individual economic interest, then state's economic interest and the latest is economic interest in the range of sub- regional, regional and global. ${ }^{11}$ The global economic relation derives from common economic interest of states which is influenced by individual economic interest within the country, hence, to meet this common economic interest, state construct extraterritorial economic agreements which is creating international legal rules. ${ }^{12}$ These legal rules are

Process, Netherlands: Martinus Nijhoff Publishers, p.4. See also Kate MacDonald and Stephen Woolcock, (2007),'Non-State Actors in Economic Diplomacy', in The New Economic Diplomacy : Decision Making and Negotiation in International economic Relations (Second Edition),Ed. by Nicholas Bayne and Stephen Woolcock (eds.),UK: Ashgate Publishing Co., p. 78.

${ }^{10}$ For the definition of International Economic Law, see Stephen Zamora, (1996).Introduction: International Economic Law, University of Pennsylvania Journal of International Economic Law, Spring 1996. p.1. Zamora argued that some scholar limit the definition of international economic law to encompass only economic relations between nations, a kind of public international law of economic relation. Conversely, can intergovernmental economic relations be effectively analyzed without resort to the effect on private transaction? Accordingly Zamora created definition of international economic law comprises a broad collection of laws and customary practices that govern economic relations between actors in different nations, includes examination of both law and policy issues on multiple levels including private law, local law, national law and international law. However, Louis Henkin argued although international economic law is blending between national law and international law, public and private law, it is still in a confinement of integral part of international law in general. The contract of concession between state and Oil Company is not constituted a treaty under international law but merely international economic relation. See also Louis Henkin, (1995). International Law: Politics and Values, Netherland: Martinus Nijhoff Publisher., p. 146. See also Pieter Verloren Van Theemat, (1981). The Changing Structure of International Economic Law, Netherland: Martinus Nijhoff Publisher., p. 13. Verloren van Themaat argued that the actual extraterritorial effect of economic law as opposed to the juridical effects limited to the domestic area. See also John H. Jackson, (1995).International Economic Law: Reflections on the "Boilerroom" of International Relations, Washington: 10 American University Journal International Law Review., p. 596-606. Jackson refers in speculation almost $90 \%$ public international law is international economic law by argued that international economic law can cover a very broad inventory of subject which is embracing the law of economic transactions, government regulation of economic matters, and related legal relations including litigation and international institutions for economic relations.

${ }^{11}$ See E.U. Petersmann, (2005). "Bridging Foundations - Human Rights and International Trade Law: Defining and Connecting the Two Fields", Human Right and International Trade, Ed. by Thomas Cottier, Joost Pauwelyn and Elisabeth Burgi, UK: Oxford University Press. p. 42. Petersmann mentioned that the agreement among states have evolved bottom up in response to the demand of private economic actors and continues to be regulated in national, regional and worldwide rules.

${ }^{12}$ See Sergei A. Voitovich, Supra Note 9,p.5. Contradictory with it, See also Richard N. Cooper, (1967), National Economic Policy in An Interdependent World Economy, Yale: Yale Law Journal June 1967., p. 1-30. Cooper mentioned that the growing economic interdependence among countries makes the successful pursuit of national economic objective or interest much more difficult. Nonetheless Van Themaat argued that interdependency of states in economic activity (in his word 'economic intervention at international level') is obvious to realize the objective of national economic interest, since historically at national level in the west, that is no longer possible to achieve a number of the objectives of national economic policy through national means only. For example of these objectives including combating unemployment and 
inevitably creating a question, whether they are binding and benefiting only state or also binding a private actor subject to the jurisdiction of the state. In this sense, Trachtman made an argument that governments increasingly recognize the issue that international economic law also governs and recognizes the interest of private person. In supporting it, the government engage in efforts to unify or organize this interest by espousing "international private law" in order to facilitate business. They often do so through public international law technique, including entry into treaty. Accordingly, private economic actors may have obligations as well as rights. Rights and obligations may arise either directly by the treaty or customary law, or indirectly by an act of transformation. But, the spectrum of transformed perspective of international economic law does not reject domestic values, including economic interest. Thus, domestic values can be maximised through international action. ${ }^{13}$ From this argument, another question then arises, what is the correlation between private economic actors and international economic law? Verloren Van Themaat made an argument that, "international economic law should meet the requirements of the infrastructure of national economic policies and national economic $l a w .{ }^{14}$ This is clearly assuming that the national economic law which is representing the national economic interest could be the primary reason to commit international economic law in the sphere of development of cross border economic activity. Hence, government as economic regulator tends to follow its constituent in avoiding laissez faire of international economic relations. ${ }^{15}$ In addition, the motivation behind any global economic agreement is the intention of state to enhance its private economic actors to gain broader benefit ${ }^{16}$ without putting aside the common interest in international economic achievement. ${ }^{17}$

inflation, a stable value of money, a well balance of payments etc. It is necessary to have international intervention in addition to international rules for liberalization and non-discriminations simply for realization of the objective of national economic interest. See Pieter Verloren Van Theemat, supra Note 10, page 15-16.

${ }^{13}$ Joel P. Trachtman, (1996).The International Economic Law Revolution, Pennsylvania: 17 University Pennsylvania Journal International Economic Law., p.5.

${ }^{14}$ Pieter Verloren Van Themaat, Supra Note 10, p. 16.

${ }^{15}$ For the comparison of this argument see Palitha T.B. Kohona,(1985). The Regulation International Economic Relations through Law, Netherlands: Martinus Nijhoff Publisher., p. 5. Kohona argued that in the contemporary world, this would result in the development of a closer relationship between international norms and domestic norms. Since international economic relation tends to affect citizen. As the world becomes more economically interdependent, more and more private citizen will find their jobs, their business, and their quality of life affected. Thus they will be more affected by the economic policy pursued by their own country on their behalf. The result of this, citizen of the country could be expected to assert them in more aggressive and require their government to respond their needs to a greater extent in development of international economic relations, and participating in formulating international economic policy.

${ }^{16}$ See Patrick Love and Ralph Lattimore, (2009).International Trade: Free, Fair and Open?, OECD INSIGHTS, p.170. These authors explore the advantage of conducting international trade both from state's focal point and individual interests. See also Robert J. Carbaugh, (2009). International Economics $12^{\text {th }}$ edition,USA: South-Western Cengage Learning., p.27-29.

${ }^{17}$ See General Assembly Resolution, A/RES/S-6/3201, Declaration on the Establishment of a New International Economic Order (NIEO), 1 May 1974. See Also Jerzy Makarczyk, (1988), Principles of a New International Economic Order: A Study of International Law in the Making, Martinus Nijhoff Publisher-the Netherlands, p.177-181. The Declaration of NIEO was supplemented by the principle of the economic common interest of all state. However this declaration stress out the duty of state to take into account the economic interest of other state, in taking economic decisions. Every states has the primary responsibility to promote the economic, social and cultural development of its people, but it is entitle to seek development 
In the context of international economic relations, private economic actors also hold an important part. As R. Ostrihansky posited "it is not government, but enterprises and individual who make most economic decisions." ${ }^{18}$ It is understood that private economic actors hold an important role in economic environment; moreover, these legal entities affect government economic policy both at the national and international level. It follows that relation between state and its private economic actors lead to the sustained economic growth in every country where most private economic actors rely upon national law for credible commitments to them. If private economic actors are conducting their activities they require assurances of their rights despite their obligations. ${ }^{19}$ The government plays a critical role in securing all economic agents by providing them a stable coalition between law and its enforcement. It is therefore understood that the establishment of GATT 1947 - followed by the WTO and GATT 1994- is merely concerned with state to secure its private economic actors involving in international trade without vexation of other state restriction or protection on trade. In addition, the WTO is necessary to fulfill the need of private economic actors for a degree of security and predictability concerning international trade ${ }^{20}$

However, the question about private economic actors in the WTO was absent from the Uruguay Round, since the focus of the WTO is not individual trader, but rather on how to accommodate the trade interest of Members and how to engage government trade policies in to benefits of global trade. ${ }^{21}$ The WTO Agreements are similar to any common international treaties which are designed to create rights and obligations between the contracting parties, but the WTO Agreements leave room for private parties to gain their rights under the agreement. It is merely up to a member to enforce it domestically. ${ }^{22}$ Accordingly, Indonesia as a WTO member endeavors to readjust its national law which is not merely to be consistent with international obligations derive from WTO rules, but also to accommodate the economic interest of private economic actors in Indonesia, to achieve better benefits and individual in-

assistance from the international community in order to overcome temporary or structural obstacles for implementation of this task.

${ }^{18}$ R. Ostrihansky, (1991). Settlement of Interstate Trade Disputes - The Role of Law and Legal Procedures, in Netherland Yearbook of International Law 1991, vol. XXII, The Hague, p. 174-75.

${ }_{19}$ These rights include rule of law or i.e. property rights and effectiveness of contract. For this argument, see Douglass North and Barry Weingast, (1989). 'Constitution and Commitment: the Evolution of Institution Governing Public Choice in Seventeenth Century England', Journal of Economic History 49 - Cambridge University Press, UK, no.4, p.803.

${ }^{20}$ John H. Jackson, (1990).Restructuring the GATT System, Royal Institute of International Affairs - Great Britain, UK, p.9-10. See also John H. Jackson, (2006), Sovereignty, the WTO and Changing Fundamentals of International Law, Cambridge University Press - UK, P. 88.Peter Van den Bossche, (2005). The Law and Policy of the World Trade Organization: Text, Cases and Materials, UK: Cambridge University Press, p. 39.

${ }^{21}$ See Steve Charnovitz, (2001).The WTO and The Rights of Individual, Journal of Intereconomics Vol. March/April, Springer-Verlag, p.1-15.

See also Qinjiang Kong,(2002).China and the World Trade Organization: a Legal Perspective, UK: World Scientific Publishing., p. 100.

${ }^{22}$ See Gregory Schaffer,(2007). 'Public and Private Partnerships in WTO Dispute Settlement: the US and EU Experience', in The WTO in the Twenty-First Century: Dispute Settlement, Negotiations and Regionalism in Asia, Ed. by Yasuhei Taniguchi, Alan Yanovich and Jan Bohanes, UK: Cambridge University Press., p.149. Schaffer mention that the reaction of private parties regarding the existence of WTO agreements in opposition or support of WTO system and its legal verdict are indicating that WTO law is relevance to states and their constituents. 
come, in the end, to raise standard of living and full employment in Indonesia. In this article, I will first discuss the concept of private economic actors as main trade players who have rights derive from the WTO Agreements.

\section{B. The Place of Private Economic Actor in the WTO Objective}

The WTO Agreements we recreated by the governments of members as public international law. ${ }^{23}$ Nothing in the WTO Agreements mentions directly rights and obligations of private economic actors. It seems that the relationship to private economic actors (or may be individual) does not exist within the Marrakesh Agreement, because as a general rule, private parties are not legal subjects of the international legal order. However, this article will prevail upon this situation, by looking closer at the essence of the WTO Agreements to discern of the place of private economic actors in the WTO.

The main objective of the Marrakesh Agreement sets out in the Preamble of Agreement of Establishing the World Trade Organization underline that"...Relations in the field of trade and economic endeavor should be conducted with a view to raising standards of living, ensuring full employment and a large and steadily growing volume of real income and effective demand, and expanding the production of and trade in goods and services."

157 members of the WTO, including industrial countries and developing countries, are bound by the duty to comply with this objective. By entering the WTO and GATT 1994, these members committed to reduce and bind most of their tariffs, to suppress many non-tariff impediments to international trade, and to avoid discrimination against all economic agents of other state in accordance with non discrimination and most - favored nation (MFN) clause. These commitments support their private economic actors to achieve better income and benefits, to promote positive result of enhancing welfare, full employment and large volume of real income for individual at the end. ${ }^{24}$ Thus, to achieve the objective of the WTO, the members should implement the WTO rules within their national legislations. ${ }^{25}$ The key objective of the WTO is the progressive removal of barriers that prevent or make more difficult beneficial exchange between producers and consumers located in different countries. The removal of barriers is intended to enhance broad empirical support for

23 See Michelle Sanson, (2002).Essential International Trade Law, Australia: Cavendish Publishing.,p.4. Sanson mentioned that although the WTO constitutes a public international trade law, but it is immediately translated into private issues such as tariffs, dumping and taxes, since in the development of international law, the distinction between private and public international trade law has less meaning.

${ }^{24}$ See G. Richard Shell, (1995).Trade Legalism and International Relations Theory: An Analysis of the World Trade Organization, Durham: 44 DUKE Law Journal., p. 877-878. Shells argued that WTO rules are a mean for globally oriented business interest and their government allies to overcome domestic resistance to free trade, reduce the legal transaction costs that states impose on the movement of goods and services across national borders, and thereby enhance consumer welfare for citizen of all nations.

For the literature review, See Bernard M. Hoekman, (2002). 'The WTO: Function and Basic Principles', in Development Trade, and the WTO: A Handbook, Ed. by Bernard M. Hoekman, Aaditya Matoo and Philip English, Washington DC: The World Bank., p.41-49.

${ }^{25}$ Implementation of WTO agreements is unable to discharge the interpretation of them, where the interpretation of WTO agreements at the national level is to be found in the way these agreements are translated into national language, re-formulated in domestic legislation, interpreted in national's tribunals and courts, and actually administered by agents of state.

See Asif H. Qureshi, (2006).Interpreting WTO Agreements: Problems and Perspective, UK: Cambridge University Press, p. 70. For example from the vantage point of the legal effect of WTO agreements, the US law promulgated the Uruguay Round Agreements Act, P.L. 103-465, 19 U.S.C.\$§ 3501. 
the proposition that WTO promotes growth, economic stability which in turn supports investment in the creation and protection economic rights for individual. ${ }^{26}$ Accordingly, it is understood if private economic actors hold on important part in trade relation among countries, ${ }^{27}$ since private economic actors are economic institutions representing the group of individuals in achieving their economic rights. ${ }^{28}$ Without legal support and protection from their governments, including national and international legal support, these legal entities find limited of economic benefits.

Broadly speaking, the WTO indirectly provides great opportunity for private economic actors to achieve their benefits, through the commitment of their governments to WTO Agreements. As Charnovitz argued that;

"similar to every international organization, the WTO connects in some ways to the individual, which inhabit the states. The main impact of the WTO on the individual derives from the substantive disciplines of trading system. In addition, the WTO also has an important connection to individuals through its procedural disciplines applying to Members, and through other means".29

Basically, The WTO Agreements have made a clear statement regarding the private economic actors. ${ }^{30}$ It shows that, first, the WTO Agreements

${ }^{26}$ See Robert D. Anderson and Hannu Wager, (2006).Human Rights, Development, and the WTO: the Case of Intellectual Property and Competition Policy, Journal of International Economic Law, Oxford University Press - UK, September, 2006, p.5.For literature review see Alan O. Sykes,(2005). 'International Trade and Human Rights: An Economic Perspective', in International Trade and Human Rights: Foundations and Conceptual Issues, Ed. by Frederick M. Abbott, Christine Breining-Kaufmann, and Thomas Cottier, World Trade Forum, Vol.5, Ann Arbor: University of Michigan Press., Chapter 4., p.69-89.

${ }^{27}$ SeeSusan Strange, (1992).States, Firms, and Diplomacy, International Affairs, London, Vol. 68, no.1, p. 1-15. In an increasingly interdependent global economy, companies and individuals, not states, are the primary vehicles for conducting international trade.

${ }^{28}$ Relation between economic rights and interest of private economic actors is, private economic actors are the institution representing the group of individuals to achieve their economic rights. According to international human rights law, individual has right to attain its economic rights, such as right to work. See article 23 (1) Universal Declaration on Human Rights 1948; "everyone has the right to work, to free choice of employment, to just and favourable conditions of work and to protection against unemployment". A healthy firm, Business Corporation or other forms of private economic actors will support the achievement of worker to achieve their economic rights. This right is entailing two obligations, obligation of owner (direct to individual) and government (as economic regulator). Economic rights are also relating to the freedom to engage in economic activities. It is similar to be free to produce and to be free to trade what we produce. In the means of production, trade and distribution, this freedom is not restricted by the states preventing from buying, selling and oper ating means of production. And the relation of employment is, if the people are allowed to own means of production, then potential employees are allowed vastly greater array of potential employment.

See also Jan Naverson, "Democracy and Economic Rights", in Ellen Frankel Paul, Fred D. Miller Jr. And Jeffrey Paul (eds.), (1992).Economic Rights, Cambridge University Press \& Social Philosophy and Policy Foundation - USA.p. 41.

${ }^{29}$ Steve Charnovitz, (2001).Economic and Social Actors in the World Trade Organization, ILSA Journal of International and Comparative Law, Vol. Spring 2001, Florida, p. 259. See also Steve Charnovitz, Supra Note 21. GATT Article X : 3(b) states that each contracting party requires to maintain judicial, arbitral or administrative tribunals or procedures for the purpose, inter alia, of the prompt review and correction of administrative action relating to customs matters.

${ }^{30}$ I.e. 1) GATT Art. XVII, Understanding on the Interpretation of Article XVII of the General Agreement on Tariffs and Trade 1994, 2) Agreement on Agricultural, Part I, Article 1 Definition of Terms, "Aggregate Measures of Support" and AMS mean the annual level of support, expressed in Monetary terms, provided for an Agricultural product in favour of the producers of the basic agricultural product or non - product specific support provided in favour of agricultural producers in general, other than support provided under programs that qualify a s exempt from reduction under Annex 2 to this Agreement." 3) 
profoundly require the Members to consider the right of private economic actors as a trade player in the WTO, and second, some agreements transmit obligation indirectly to private economic actors and the government should ensure to take such measure to accommodate its private economic actors in complying these obligations.

Perhaps the most apparent view in the relation between private economic actors and the WTO is when the government applies both substantive and procedural rights in its domestic regulations. As Charnovitz mentioned that "like the GATT, the WTO does not accord rights directly to individuals, but rather mandates that member governments to do so"31 This argument will lead to the next question; do private economic actors have rights that derive from the WTO Agreements? A pertinent answer will be elaborated below in coherence with the arguments before.

\section{Do Private Economic Actors have Rights that Derive from the WTO Rules?}

Substantive right derives from the WTO rules is recognized as economic right which is the obligation of the state to fulfill it.Petersmann also argued that the WTO Agreements guarantee of freedom of trade ${ }^{32}$, non-discrimination, and rule-of-law serve "constitutional functions" for protecting, enlarging, regulating, and mutually balancing equal freedoms and other individual rights across frontiers. ${ }^{33}$ In this sense, without a doubt, economic substantive right is deployed by WTO to pursue the interest of individual through the obligations of governments.

\section{Substantive Rights}

There are two characteristic of substantive rights that derive from the WTO Agreements, direct and indirect substantive rights. The indirect substantive rights exist when a government set up a new regulation based on non-discrimination, MFN Treatment and National Treatment, which is in the WTO Agreements these treatments are obligations of the member to other

The General Agreement on Trade in Services (GATS): Objective, Coverage and Disciplines. 4) Agreement on Textiles and Clothing Article 1 (2),Members agree to use the provisions of paragraph 18 Article 2 and paragraph 6(b) of Article 6 in such a way to permit meaningful increases in access possibilities for small suppliers and the development of commercially significant trading opportunities for new entrants in the field of textiles and clothing trade.

${ }^{31}$ Charnovitz, Supra Note 21.

${ }^{32}$ E.U. Petersmann, (2000). "Judicial Protection of Economic Freedom in National and International Law: Time for Bringing Rights Home”, in Judicial Review in International Perspective (Liber Amicorum, in Honour of Lord Slynn of Hadley),Ed. By Mads Andenas and Duncan Fairgrieve, Kluwer Law International the Netherlands, p. 475-476. The WTO rules generally protect freedom of trade (e.g. Articles II,XI GATT, XVI GATS), most favored nation treatment (e.g. Articles I GATT, II GATT, II GATS, 4 TRIPS Agreement), national treatment (e.g. Article III GATT, XVII GATS), private property rights ( the TRIPS Agreement), rule of law and broadly defined public goods (GATT Article XVII-XXI, GATS Articles XIV, XIV bis, Articles 6-8, 30-31, 40 of the TRIPS agreement) for the benefit of private traders, investors, producers and consumers.

${ }^{33}$ E.U. Petersmann, (2008). 'Constitutionalism and WTO Law: From a State Centered Approach Towards a Human Rights Approach in International Economic Law', in The Political Economy of International Trade Law (Essays in Honor of Robert E. Hudec), Ed. By Daniel L. M. Kennedy and James D. Southwick, UK: Cambridge University Press., p. 33. 
members, but also indirectly rights of private economic actors of the member. $^{34}$

A direct substantive right has made by the WTO creators when intellectual property right has been created to accommodate individual property right. The Agreement on Trade -Related Aspects of Intellectual Property Rights (TRIPS) requires Members to create and to grant intellectual property rights to its national and nationals of other WTO Members. This right is peculiar since it is applied to individuals. The person who is granted IP rights is permitted to collect rents and to prevent others from infringing on their privileges for a specified period. ${ }^{35}$ TRIPS is a set of IP rights agreements that created an obligation for government to protect IP rights of individuals through domestic law. ${ }^{36}$ These rights are economic substantive rights directly from the WTO rules. This right also indirectly exists for individual through the implementation of the objective of the WTO.

The General Agreements on Trade in Services (GATS) also imply substantive right directly to both individual and private economic actors such a service supplier. The substantive right for individual under the GATS is free movement for natural person to supply service. ${ }^{37}$ In addition, the substantive rights for private economic actors derive from service mode of cross border supply and commercial presence. The state is obliged to impose substantive right directly to service supplier or individual. In terms of substantive right for individual and substantive obligation for government ${ }^{38}$, state must apply MFN and national treatment principles, but does with a twist. Similar to other WTO Agreements, the MFN principle prohibits discrimination, whether it is intentional or unintentional, and applies MFN principle regardless of the nationality of service suppliers. ${ }^{39}$ In the GATS, state members should provide the service supplier transparency regarding the schedule of commitment in order to achieve market access in services.

${ }^{34}$ See E.U. Petersmann, Supra Note 32.

35 WTO Annex 1C, Agreement on Trade-Related Aspects of Intellectual Property Rights, available at http://www.wto.org/english/docs e/legal e/27-trips.pdf, last visited 12 April 2010. See also PeterTobias Stoll and Franck Schofkopf, (2006), WTO, World Economic Order, World Trade Law, Netherlands: Martinus Nijhoff Publisher., p.207-220.

${ }^{36}$ See also Robert D. Anderson, Hannu Wager, Supra Note 26, Anderson and Wager mentioned that TRIPS created a minimum protection of IPR rights of individual that leaves a fair amount of leeway to Member countries to implement its provisions within their own legal system and practice and fine-tune the balance in the light of domestic public policy considerations.

37 GATS Annex on Movement of Natural Persons Supplying services Under the Agreement, available at http://www.wto.org/english/docs e/legal e/26-gats.pdf, to compare this argument freedom of movement of natural person is also recognized by EC Treaty.

${ }^{38}$ See David P. Fidler, Nick Drager, Carlos Correa and Obijiofor Aginam, (2006). 'Making Commitments in Health Services under the GATS: Legal Dimensions, in International Trade in Health Services and The GATS: Current Issues and Debates, Ed. By Chantal Blouin, Nick Drager and Richard Smith, the World Bank, p.150-155. General obligations and disciplines derives from GATS is known as substantive duties and procedural duties. State is obliged to perform these obligations in order to achieve substantive rights of individual and private economic actors under GATS.

${ }^{39}$ Ibid, GATS Part II General Obligations and Disciplines, Article II Most-Favoured-Nation Treatment: With respect to any measure covered by this Agreement, each Member shall accord immediately and unconditionally to services and services suppliers of any other Member treatment no less favourable that that it accords to like services and services suppliers of any other country. 


\section{Procedural Rights}

To assist private economic actors in gaining the benefit of the WTO Agreements, the WTO creators established a number of procedural and administrative requirements to be met by the government of members. These requirements provide indirect procedural right to private economic actors. Procedural right is right to due process regarding the implementation of the WTO Agreements.

\section{a. Procedural right according to GATT}

Article X 3(a) of GATT requires each party to administer in a uniform, impartial and reasonable mannerall its laws, regulations, decisions and rulings of the kind described in paragraph 1 of this Article. This article constitute procedural obligation of state to manage all its law, regulations, decisions and rulings in order to give such information for trading partner both states and their enterprises ${ }^{40}$ Article X of GATT enshrines the reference of transparency and due process which has been quoted by the WTO Panel and Appellate body. The 'due process' and transparency constitute a procedural right that implies to private economic actors, in gaining its benefit from GATT.

\section{b. Procedural Right According to TRIPS}

The procedural right or due process right set out in TRIPS is the important stage in dealing with the enforcement of IPRs. TRIPS lays down minimum standard that must be reflected in the domestic laws of the WTO Members states. However, the TRIPS standard on enforcement of IP rights does not attempt to harmonize member's law and practices. The general provisions under Section I Part III of TRIPS established the obligation that members of the WTO shall ensure the availability of enforcement procedures under their laws. The availability of the enforcement procedures under domestic law must be fair and equitable and must permit effective action against any infringement of IP right covered by TRIPS. The application of the enforcement procedures shall be in a manner as to avoid the creation of barriers to legitimate trade and provide for safeguards against their abuse. Article 41 (5) of TRIPS confirm that the obligation for the availability of enforcement procedures does not create any obligations to put in place a judicial system, and for allocation of resources for enforcement of IP right as a distinct from enforcement of law in general. TRIPS is specific on obligations of a WTO member to make available effective mechanisms for enforcement without putting standard on measuring the operational and functional aspect of the mechanism in each country. ${ }^{41}$

${ }^{40}$ See European Communities - Regime for the Importation, Sale and Distribution of Bananas - AB1997-3 - Report of the Appellate Body, (WT/DS27/AB/R), 09-09-1997, Appellate Body clarified that the uniformity requirement is not a general non discrimination obligation, such an MFN requirement. In other words, it does not deal with the substance of measure at issue, but only their administration.

See also W.J. Davey, 'Dispute Settlement Practice Relating to GATT 1994', in The WTO Dispute Settlement System 1995-2003 (Studies in Transnational Economic Law Vol. 18),Ed. By Federic Ortino and ErnstUrlich Petersmann, Netherlands: Kluwer Law International, p.210.

${ }^{41}$ Ermias Tekeste Biadgleng, (2008), 'The Development Balance of the TRIPS Agreement and En- 


\section{c. Procedural Right according to GATS}

GATS Article VI (2) provides a basic framework for minimizing the distortions of trade created by domestic regulation. The regulations that affect service bound by national commitments are to be administered in a reasonable, objective and impartial manner. To paraphrase Article VI, member countries must provide procedures for the review of the regulation at the request of service suppliers, and must be based on objective and transparent criteria. The review itself must not be more burdensome than necessary to ensure the quality of the services. And in the case of licensing procedures, it must not be restricting the supply of the service. ${ }^{42}$

Article VI of GATS explicitly recognizes the right of service supplier to information on regulatory and administrative decisions, to judicial and administrative review and appeals process, and contains no provisions on notifications to the WTO or on bilateral consultations with other WTO members. ${ }^{43}$

\section{III.Indonesia and the WTO}

Indonesia ratified the Agreement Establishing of the WTO in November 1994, by the Law No. 7/1994. The country has in principle adopted a quite liberal foreign trade regime and has taken a number of important steps to reduce protection. Indonesia is also obliged to make reassessment of its national law in conformity with the WTO Agreements, where the essence of the WTO Agreements is to accommodate rights of private economic actors to achieve international trade benefits. Thus, the next part of this article is to discern peculiar issue regarding to what extent is Indonesia dealing with the rights of private economic actors that derive from the GATT, GATS, TRIMs and TRIPs.

\section{a. From the WTO Preamble to the Constitution of Indonesia}

A constitution is a fundamental principle accommodating rights of individual within a country. Indonesian Government has foreseen the importance of amending the constitution in regard to economic policy and regulation

forcement of Intellectual Property Rights', in Interpreting and Implementing the TRIPS Agreement Is It Fair?, Ed. by Justin Malbon and Charles Lawson, Edward Elgar Publishing- UK, p. 120. Biadgleng explained according to Article 41 (5), TRIPS requires countries to make available to right holders civil judicial procedures concerning the enforcement of any IP right covered by TRIPS, and criminal procedures and penalties at least in cases of willful trademark counterfeiting or copyright piracy ion a commercial scale. Countries should adopt procedures to enable right holder to lodge an application with competent authorities, for the suspension of the release into free circulation of goods validly suspected to involve trademark counterfeiting or copyright piracy. The Judicial authorities should have the authority to order disclosure of evidence, injunctions, damages, prompt and effective provisional measures and disposition of infringing goods and materials and implements the predominant use of which has been in the creation of the infringing goods.

42 See General Agreement on Trade in Services, Article VI available at http://www.wto.org/english/docs e/legal e/26-gats.pdf, last visited 12 April 2010.

See also Eugene Beaulieu, (2008). 'Trade in Service', in Handbook on International Trade Policy, Ed. by William A. Kerr and James D. Gaisford, UK: Edward Elgar, p.157.

${ }^{43}$ OECD, (2001). Trade in Services: Negotiating Issues and Approaches, OECD Publications Services, p.99 
in to conformity with trade liberalization. The amendment of Article 33 (4) of Indonesian Constitution is solely reflecting the economic democracy, where all constituents can participate to achieve better income and trade benefits. The amendment was created to accommodate open market where all economic actors in Indonesia can participate in trade liberalization, to achieve full employment and to raise standard of living.

Indonesia is implicitly instituting the rights and obligations of private economic actors within national law. The rights derive from the Indonesian constitution which is promulgating right to conduct economic activity. It appears in amendment of Article 33 of Indonesian Constitution. The original Article $33^{44}$ is recognizing state as 'major economic actor' in controlling economic activity, therefore, after 2002; article 33 was amended in conformity with the globalization concept which private economic actors are also holding predominant part in Indonesia's economy equilibrium. ${ }^{45}$

\section{b. GATT is Milestone to Open Market in Indonesia}

Since Indonesia actively joined in GATT negotiations in 1994, the support of government for trade liberalization is relatively strong. Indonesia has been liberalizing its trade regime and has taken a number of important steps to reduce protection. The numbers of laws promulgating trade liberalization such as lowering tariffs and reduces non-tariffs barrier, have been conducted from central level of government to regional autonomy. Since January 2002, 67.4 percent of Indonesia's tariff lines were assessed import duties ranging between zero to five percent and Indonesia un-weighed tariff is 7.3 percent. ${ }^{46}$ Today, the government continues to reduce the number of products subject to import restrictions and special requirements. In order to accommodate economic actors in international trade, Indonesian Government actively seeks to improve transparency. The government offices provide copies of laws, regulations, instructions, application forms and similar subsidiary instruments readily available to the private economic actors. However, the overlapping instructions seem to be the most complain about, since the system still needs to be improved. Many private economic actors complained that there was no one stops information-center publicly accessible to look for regulations issued by the government.

Starting from 2005, the government provided these actors with a meaningful notice and an opportunity to request and to comment on draft laws or legislative amendments affecting trade, direct through the ministry of

${ }^{44}$ Article 33 of the Constitution was originally inspired by a broad mix of leftist, nationalist and anti colonialist ideals that were influential at the time the constitution was drafted in 1945 . Accordingly, this article required state to control important branches of production and natural resources, in the basis of people economy discourse. See Vedi R. Hadiz, (2004), 'The failure of State Ideology in Indonesia: the Rise and Demise of Pancasila', in Communitarian Politics in Asia, Ed. By Ben Huat Chua, London: Routledge., p-148-61. See also Mohamad Mova Al'Afghani, (2006).Constitutional Court's Review and the Future of Water Law in Indonesia, the Law Environment and Development Journal 2 (1) - London/New Dehli, p.1-18.

${ }^{45}$ Amendment of Article 33 sets out that the organization of the national economy shall be based on economic democracy that upholds the principles of solidarity, efficiency along with fairness, sustainability, keeping the environment in perspective, self-sufficiency, and that is concerned as well with balanced progress and with the unity of the national economy.

46 The WTO Data, Indonesia, available at http://stat.wto.org/CountryProfile/WSDBCountryPFView.aspx?Language=E\&Country=ID 
trade. ${ }^{47}$ The regional government conducts effort to readjust the local regulation with central government. These efforts are deriving from Article X 3 (a) of GATT as procedural rights for private economic actors to involve in open market in Indonesia.

\section{c. Application of substantive and procedural rights derive from WTO rules}

In order to apply substantive and procedural rights for private economic actors in Indonesia, the government began with promulgating new law in specific and crucial matter of WTO Agreements, such as GATS, TRIPs and TRIMs. Although to accommodate the demand of private economic actors, the government is facing some difficulties in applying these agreements.

\section{Financial and Telecommunications services in Indonesia}

Indonesia felt comfortable enough to deal with trade in services when it was further spelled out how progressive liberalization was to be undertaken. The two sectors in which Indonesia made considerable commitment were financial service and telecommunications. The authorities recognized the importance of more open and competitive financial and telecommunication service for the modernization of the economy. ${ }^{48}$

After the financial crisis in 1997, the Indonesian Government continues to implement GATS Agreement in financial service. In order to impose substantial right for services provider in financial sectors, government promulgated Law No 10/1998 as amendment of Law No/7 1992 of Indonesia's banking system. The main factor for liberalization in financial sectors proposed by Law No 10/1998 is to widely open for commercial presence of foreign bank or joint venture between domestic and foreign bank in Indonesia. ${ }^{49}$ In order to provide substantive right for private actors in financial service according to GATS, the government through Bank Indonesia (central bank of Indonesia) continues to provide license up to $51 \%$ shares in joint venture, exceptional condition up to $99 \%$ shares. These regulations propose several objectives, inter alia 1) enhancing the quality of domestic banking, 2) stimulating domestic banking supervisory system, 3 ) enhancing accessibility to International financial market system. However, contradictory argument develops in respect to financial liberalization in commercial presence - joint venture, presence of branch or representatives - will eliminate compatibility of national banks; hence, they enforce to be able to merge or acquisition in order to keep up the banking stability.

Liberalization on telecommunications can help the modernization of the infrastructure of Indonesia so long as the process is made gradually and

47 The ministry of trade provide information and opportunity to request and to comment on drafts laws and legislative for businesses and enterprises, available at http://www.kemendag.go.id/en/ perdagangan-kita/

${ }^{48}$ See H.S. Kartadjoemena, Services Agreement in the Uruguay Round: A Preliminary Assesment of What Could be Expected by SEACEN Countries, Keynote Speech by Ambassador H.S. Kartadjoemena on the Occasion of the SEACEN Central Bank Governors Conference, Jakarta January 30, 1991.

${ }^{49}$ See GATS Annex on Financial Services. See also H.S. Kartadjoemena, (1986)‘ndonesia’s Trade Policy: Problems and Options', Selected Key Policy Issues in the Indonesian Economy, Ed. by H.S. Kartadjoemena, Springer-Verlag. p. 120-31. For a summary of the extensive reform of the banking sector, see the paper prepared by a team from the Economics and Statistics Department of Bank Indonesia, Interest Rate after the Financial Deregulation in Indonesia: Some Key Policy Issues. 
Indonesia undertakes domestic arrangements that are suitable for its own needs. Thus, in 1997, Indonesia negotiated Schedule of Commitment (SOC) in regard to the implementation of GATS Annex on Telecommunications. Before entering the WTO Agreements, telecommunications service in Indonesia was ruled by Telecommunications Law No.3/1989 which provides the fundamental statute for Indonesia's telecommunications framework. The Primary purpose of the 1989 Telecommunications Law was to open the telecommunication sector to limited private-sector participation. The major provider of telecommunication service was state owned enterprises. In 1999, after Indonesia signed the SOC in 1997 with respect to WTO's Basic Telecommunications Agreement, a new Telecommunications Law (Law no. 36/1999) was enacted, replacing the 1989 Law. It is setting a foundation for an even more liberalized on telecommunications sector. This law was replacing the foundational "basic services" and non basic services" with a "network provider" and "services provider" designation. Network providers are private economic actors that provide infrastructure, and service providers are private economic actors that provide value-added services over this infrastructure. ${ }^{50}$ Although in the beginning of the implementation of the new telecommunications law, the main feature of contract was joint venture between major provider (PT. Telekomunikasi Indonesia and PT. Indonesia Satelindo) and local providers, the main idea of the new law is supporting domestic industry in telecommunications sector and abolishing the monopoly in telecommunications market. The telecommunications industries became a streamline industry in Indonesia after the promulgation of the new law; however the problem concerned is lack of transfer of technology and technical assistant. The government therefore promulgated 'blue print telecommunications policy' in Ministerial Decree No. 72/1999. This decree purpose to: 1) enhance performance in telecommunications sector in order to involve in globalization, 2) liberalization in telecommunication sector without monopoly, 3) transparency and certainty in regulation, 4) providing opportunity for strategic alliance between domestic provider and foreign provider, 5) providing opportunity for SMEs, and 6) facilitating full employment opportunities. ${ }^{51}$

\section{Investment sector}

The most crucial sector after the multidimensional crisis is the investment sector. It cannot be said that Indonesia is hesitant to foreign investment. In fact it has been searching for a way to continue to attract Foreign Direct Investment. However, the issue is even more urgent because foreign investment is needed to recover from the current crisis. The concept of foreign investment in TRIMS appears worrisome. At the broader level, a concept such the right of establishment is alien to a country sensitive about the notion of sovereignty. Since the establishment, from the national perspective, is a privilege, which, though contractually bound once it is granted, remains a privilege granted by government, and it would be viewed as an infringement of the notion of sovereignty. ${ }^{52}$

\footnotetext{
${ }^{50}$ Darrel E. Owen, Idris F. Sulaiman, Sonia Baldia and Steven P. Mintz, (2001), Indonesia-Information and Communications Technologies (ICT) Assessment: Technical Report of January 16-February 5, USAID/ECG, Jakarta Indonesia, p.5

${ }^{51}$ Ibid, p. 31.

${ }^{52}$ An attempt to deal with Indonesian investment issues related to the WTO was initiated with
} 
Nevertheless, the crisis has led Indonesia to the new investment law in accordance with TRIMs. The new law is aimed at invigorating investment in the Indonesian economy, creating jobs and reducing poverty. In 2007, the government promulgated new investment law, Law No 25/2007. This law is adopting national treatment principle in accordance with GATT 1994 principle as a manifestation of substantive right for private economic actors in investment sectors, including in the broad terms, allows greater mobility for foreign professionals if such skills are not found among the local employees and it opens up almost to all sectors of the economy with the guarantee that the government will not enforce nationalization. ${ }^{53}$ According to this law, those foreign investors that are partners with local business entities, will also be entitled to obtain tax incentives. The most crucial matter in this law is permissive in land acquisition for foreign investors, with lease for an initial 60 years with an option to extend for another 35 years. ${ }^{54}$

But this law is subject to contradictory arguments. As mentioned before, worrisome seemed appears when Indonesia ratified the WTO Agreements. The idea of infringement of sovereignty tends to be a major contradictory argument when the Law No.25/2007 was promulgated. Two political parties in Indonesia rejected the law on the basis that it provided inadequate protection to local businesses who could not compete on the basis of capital and expertise. ${ }^{55}$ Another dissent voice about new investment law came from Islamic political party which mentioned that new law in investment has clear leaning towards a capitalist mindset which also disregard Islamic interest and foreign capital as move to place "Indonesia for sale". ${ }^{56}$

In spite of dissenting voices regarding the investment law No. 25/2007, the government keep up to implement this law, since the development of investment basically for micro-scale, medium scale business and cooperative enterprise or SMEs to cooperate with large-scale enterprise. The government through this law encourages SMEs to enhance capacity to compete, to support innovation, market extension and wide distribution of information. Thus, the government issued the Instruction of the President of the Republic Indonesia No.6/ 2007 in regard with Policies to Accelerate Development of the Real Sector and Empower Micro, Small and Medium Enterprise, and Law No. 20/2008 regarding Micro, Small and Medium Scale Enterprise.

\section{Intellectual Property Rights}

Intellectual property right (IPR) in Indonesia is a new issue. Historically and culturally, Indonesian people do not recognize rights of protection in intellectual property. Most of Indonesians still hold to Adat norms (cultural

prominent lawyers in 1995 to develop a coherent approach for dealing with foreign investment and the broader policy implications for Indonesia. See the volume of publication of discussion papers by Bank Indonesia (1995), Rezim Investasi di Indonesia dalam Kaitannya dengan Perjanjian Hasil Uruguay Round, Ed. by H.S. Kartadjoemena, BI- Jakarta, p. 1-234.

${ }^{53} \mathrm{Art} .3(1)(d)$ : The principle that foreign and domestic investors are equal before the law, Art. 4(2): The principle that foreign and domestic investors shall have equal opportunity, Art. 6(1): all investors shall be treated equally, and Art. 6(2): recognizes that bilateral agreements regarding investment may be made.

54 Undang-undang No. 25 tahun 2007 tentang Penanaman Modal, see also iNusantara Network, Indonesia's Investment Law 2007, available at: http://www.fdi.net/documents/WorldBank/databases/ indonesi/indonesia_investment law 07.pdf

${ }^{55}$ See "Dua Partai Politik Menolak Undang-undang" available at: www//tempointeractive.com

${ }^{56}$ See "Saling Tuding di Balik Investasi", available at http://www.media-indonesia.com 
norms) that do not recognizes private-sector, individual ownership in intellectual works or inventions. Although cultural norms in Indonesia recognize individual possession of material goods, it does not allow individual rights of possession to override principles of the public interest and social function of goods. This mindset therefore made major Indonesian people look askance in to the enforcement of IPR law in Indonesia. Anton Christoph even mentioned that "IPR laws in Indonesia promulgated in early 1990s was due to economic pressure from western countries, rather than a genuine interest in intellectual protection itself". ${ }^{57}$ Furthermore, when Indonesia had agreed to negotiate IPRs in the Uruguay Round, it was primarily a political concession to other developed countries which felt strong about the subject. Indonesia gradually recognizes that strong national legislation on intellectual property might encourage foreign investors to come in with the kind of technology transfer that they would not be willing to make if effective intellectual property protection does not exist. To this end, in the early 2000s, Indonesia government issued Law No.30/2000 regarding Trade Secret; Law No.31/2000 Regarding Industrial Design; Law No.32/2000 regarding Lay-out Design of Integrated Circuit; Law No.14/2001 regarding Patents; Law No.15/2001 regarding Trademark and Law No.19/2002 regarding Copyrights in accordance with TRIPs.

The Government enforces those laws both in civil remedies and criminal procedures. In the civil remedies, there are two alternatives for IPR holder to settle an IPR disputes against the infringer of the right.1) The dispute is settled by the commercial court, or 2) the dispute is settled by arbitration or any other alternative dispute resolution. If the holder claims damage or cease all infringements, they should file a lawsuit against the infringer to the Commercial Court which jurisdiction covered the domicile of the infringer. The infringement of IPR also constitutes as crime. Mainly crimes against IPR are classified as crimes upon formal complaint or charge, except for crimes against copyright which classified as ordinary crimes. The law also implies sanction in criminal procedures, for example the Copyright Law (Art. 72), mentioned that any person who deliberately and without right conduct any copyright infringement shall be sentenced to imprisonment of at least 1 month and/or fine at least one million rupiahs or imprisonment of at most 7 years and/or a fine at most five billion rupiahs. ${ }^{58}$

However, the enforcement of IPR Law in Indonesia seems like open up pandora's box. To be able to enforce the law down to end-user infringement, the police are normally taking ex officio actions, although in many cases they take these actions without notifying right holders and administer fines without consulting the industries. Hence in 2000, the authorities had learned a bitter lesson, when the police raided street vendors at shopping area in Jakarta to confiscate illegal CDs, VCDs, DVDs and CD-ROMs of music and movies. Unexpectedly, the raid was creating severe rioting. It raised some arguments that the piracy phenomena were appeared because of the economic crisis condition in Indonesia. Although this argument will not withdraw government effort to enforce IPR Law, but it still becomes a major problem for gov-

\footnotetext{
${ }^{57}$ Antons Christoph, (1991), The Development of Intellectual Property Law in Indonesia: From Colonial to National Law, A Survey, 22 International Review of Industrial Property and Copyright Law, VCH Verlags gesellschaft - Frankfurt, p. 374.

58 Enforcement of Intellectual Property Rights in Indonesia, Report Prepared By DGIPR Indonesia, available at http://www.ecapproject.org.
} 
ernment to keep on its track to enforce the IPR law.

\section{Small and Medium Enterprises (SMEs) ${ }^{59}$}

When talking about private economic actors, the common perception will lead to the Multinational Corporation or Holding Company. However, it will become a misleading perception especially in the developing country. In fact, Small and Medium Enterprises basically is main trade player in many developing countries. In Indonesia, a 99, 98\% of the total enterprises are SMEs. ${ }^{60}$ These SMEs are also holding substantive and procedural rights derive from the WTO that is accommodated by the government. In this section, I provide a brief discussion to what extent Indonesia also deals with the rights of SMEs that derive from the WTO Rules.

In general, SMEs achieve decent level of productivity especially of capital and large amount of employment, thus, SMEs are a conducive and a flexible industrial structure in Indonesia. It is particular important as a vehicle for promoting indigenous Indonesian business and therefore as a means of asset redistribution along ethnic lines. ${ }^{61}$ The development of SMEs is a major part of economic development in Indonesia. SMEs are also flexible in responding economic crisis. Its capacity to shift from one product to another product is enable them to do relatively better under volatile macro conditions than big firms which produce more standardize products, where reorganization of the assembly line takes time. ${ }^{62}$ Nevertheless, SMEs in export activities are still weak compare to large enterprises, because the majority of export-oriented SMEs do not export directly, but indirectly through intermediaries such as traders, exporting companies, or trading houses, or subcontracting arrangements with large enterprises.

When Indonesia ratified the agreements of the WTO, many SMEs vociferously disagreed with the implementation of these agreements, due to the lack of trade facilitation for them to involve in international trade under the WTO Agreements. In addition, some SMEs declared that limited access to raw materials, capital, technology, information, market for their product, lack of business outlets, and location, as well as networking and partnership become a major problem for them to involve in international trade. In order to empower the SMEs in international trade and to compete in the course of economic modernization and trade liberalization, therefore, it is necessary for Indonesian Government to create a conducive trade market for financial and

${ }^{59}$ According to Law No.9/1995 regarding Small, Medium Enterprises in Indonesia, definition of SMEs is: 1) A business that owns net assets worth 200 million rupiahs or less. However these assets shall not include land or buildings. 2) Annual Sales of 1 billion rupiah (net) or less. 3) Owned by a citizen of Indonesia. 4) An independent economic entity, which is not a subsidiary or branch of a large or medium enterprise, and is not directly or indirectly controlled (including where the operator is dispatched from a large or medium enterprise) by a large or medium enterprise. 5) The business is managed by an individual, an unincorporated entity, or a cooperative organization.

${ }^{60}$ Available at http://www.depkop.go.id/

${ }^{61}$ See Hal Hill, (2001).Small and Medium Enterprises in Indonesia: Old Policy Challenges for a New Administration, Asian Survey, Vol. 41, No. 2 (Mar. - Apr., 2001), US: University of California Press., p. 248270 .

${ }^{62}$ Albert Berry, Edgard Rodriguez and Henry Sandee, (2002), 'Firm and Group Dynamics in the Small and Medium Enterprise Sector in Indonesia', in Small Firm Dynamism in East Asia, Ed. By Farrukh Iqbal and Shujiro Urata, Netherland: Kluwer Academic Publisher., p. 141-161. 
non-financial assistance, and trade facilitation. ${ }^{63}$ To this end, the government proposed new market-oriented and demand-driven SMEs program such as the establishment of financial institution which can provide finance to SMEs on an open and accessible basis, the effective provision of (non-financial) business development service to SMEs, and the formation of strategic alliance between SMEs and other large firms. ${ }^{64}$ Moreover, in order to provide substantial and procedural rights derive from the WTO rules, the government is also supporting SMEs as main trade player of WTO rules by providing some special attention in investment, export-import facilitation and IPRs.

In the investment sector, the government through the Investment Policy Reforms Initiative (IPRI) established in 2004, proposed the encouragement and facilitation for private sector investment. This reform mainly to implement transparency, predictability and market oriented policies, especially Foreign Direct Investment for SMEs.

In Trade Facilitation to support export-import for SMEs in Indonesia, the government has introduced several measures to increase the export capacity of SMEs. In accordance with GATT Article VIII, the government supports the work of National Agency for Export Development (NAFED) which has been established in 1971, to improve trade facilitation for SMEs. NAFED maintains a comprehensive database of thousands of companies, includes SMEs. Its main tasks and functions are (1) to formulate policies and establish guidelines for encouraging and supporting the expansion of non-oil and gas export, (2) to provide information services and technical advisory services for export development, (3) to expand the range of export product and markets. Although NAFED does not focus on SMEs but the most prominent costumers are SMEs, thus, since the government focus on supporting SMEs in international trade, many SMEs used NAFED to involve in international trade. ${ }^{65}$

Another crucial matter to provide substantial rights for SMEs is the IPRs. The lack of information of IPRs among SMEs in Indonesia becomes a major hesitancy for them to protect their intellectual knowledge. Thus, in 2003, the Minister of Law and Human Rights issued a Decree No. M/11/ PR/07/06/2003. The decree aims to provide SMEs to gain access to IP-related information/data, to allow applicant to lodge IP applications at the Provincial Offices of Ministry of Law and Human Rights, to educate SMEs concerned with IPRs, to encourage innovations through the granting of patent rights, and to protect domestic brands and to promote industry. Another important measure taken by the government is through the stipulation of Government Regulation No. 75/2005 regarding Types and Tariff of Non-Taxes Government Revenue. This regulation provides some special fees for applications by SMEs. In 2008, the government then set up an Innovation Center for Micro, Small and Medium-sized Enterprise (IP-MUKM). This center is a positive effort to build SMEs based on innovation and technology which is collaborating with Ministry of Industry, Indonesian Institute of Science (LIPI), National Agency

${ }^{63}$ See Report of State Ministry of Co-operatives and Small/Medium Enterprises, (2001), Co-operative and Small/Medium Enterprises Development in Indonesia, 3 Journal of Economic Cooperation no. 22, p. 1-26

${ }^{64}$ Ibid

${ }^{65}$ Tulus Tambunan, (2009). Facilitating Small and Medium Enterprises in International Trade (Export): The Case of Indonesia, Paper Presented in Asia-Pacific Trade Economists' Conference: 'Trade Led Growth in Time of Crisis', UN-ESCAP, 9 November 2009, p. 21-22. 
for Study and Application of Technology (BPPT), State Ministry of Technology and Directorate General of Intellectual Property Right. One of the objectives of this center is to provide information on expired patents that can potentially be used and developed by SMEs. ${ }^{66}$

\section{Conclusion}

This article emphasized the existence of private economic actor's right that derives from the WTO Agreements. The rights of private economic actors in general are instituting to what extent the dependency of state to their economic actors and vice versa. These private economic actors are stanchion for economic growth in each member, thus state as economic regulator should be more perceptible in protecting its private economic actors. In this sense, it refers to all legal rules which mitigate the conduct of private economic actors within its territory or cross border. This dependency can be measured by economic indicators (such as labor, export-import, investment, internal market equilibrium, income per-capita and GDP). The rationalization of protection the right of economic private actors tends to support elimination of studious economic stalemate in every country, i.e. uncertainty of law enforcement, constraint of right until decreasing of GDP.

A state is also providing broad possibility for its economic actors to conduct their activities in a large spectrum such as cross border supply and demand in the sphere of international trade in order to gain their benefits. But the most important intention to involve in global trade is that the global economic relation derives from common economic interest of states which is influenced by individual economic interest within the country, hence, to meet this common economic interest, state construct extraterritorial economic agreements which is creating international legal rules. Thus, state should be willing to gain economic relation in the virtue of international economic relation.

Indonesia has been trying to engage in the WTO rules with certain agenda to support its private economic actors, especially SMEs, in order to achieve the benefits of global trade for all Indonesian nations. (In 5 years, more than half of SMEs in Indonesia increase their international trade balance). Although, in terms of implementation of the WTO Agreements, some contradictory arguments exacerbate the effort of Indonesia to total adopt the WTO rules into national law, but, Indonesian Government is more foreseeing the benefits of WTO rules than the skeptical point of views regarding of it. Furthermore, Indonesian government is supposed to focus on the interest of SMEs, local business and local investment by using total benefits as developing country member in the WTO without necessary set aside the obligation derives from the WTO Agreements. Indonesia Government also needs to be more vocal in every WTO round in regard with the interest of national economic actors.

In conclusion, this article gives a different point of view concerning the

\footnotetext{
${ }^{66}$ Ministerial Decree No. M/11/PR/07/06/2003 available at http://www.legalitas.org/database/ puu/2003/kepmenkehM11-2003.pdf

Government Regulation No. 75/2005 available at http://ngada.org/pp75-2005.htm
} 
relation between the WTO Agreements and private economic actors in Indonesia. First, private economic actors have rights direct or indirectly derive from the WTO Agreements, and second, Indonesian Government suppose to conduct international trade by focusing more to the rights of private economic actors, thus, the implementation of the WTO Agreements in Indonesia does not merely on behalf of fair global trade but also to accommodate interest of private economic actors or individual at the end.

\section{Bibliography}

\section{Books and Articles}

Anderson, Robert D., and Wager, Hannu. (2006).Human Rights, Development, and the WTO: the Case of Intellectual Property and Competition Policy, Journal of International Economic Law September 2006, Oxford University Press Altvater, E.

The Future of the Market: An Essay on the Regulation of Money and Nature after the Collapse of Actually Existing Socialism, Verso press - London.

Al'Afghani, Mohamad Mova.(2006).Constitutional Court's Review and the Future of Water Law in Indonesia, the Law Environment and Development Journal 2 (1), London/New Delhi.

Bank Indonesia. (1995). Rezim Investasi di Indonesia dalam Kaitannya dengan Perjanjian Hasil Uruguay Round, Ed. by H.S. Kartadjoemena,

Beaulieu, Eugene. (2008). 'Trade in Service', in Handbook on International Trade Policy, Ed. by William A. Kerr and James D. Gaisford, UK: Edward Elgar.

Berry, Albert, Rodriguez, Edgard, and Sandee, Henry.(2002). 'Firm and Group Dynamics in the Small and Medium Enterprise Sector in Indonesia', in Small Firm Dynamism in East Asia, Ed. By Farrukh Iqbal and Shujiro Urata, Netherland: Kluwer Academic Publisher.

Biadgleng, Ermias Tekeste. (2008). 'The Development Balance of the TRIPS Agreement and Enforcement of Intellectual Property Rights', in Interpreting and Implementing the TRIPS Agreement Is It Fair?, Ed. by Justin Malbon and Charles Lawson, UK: Edward Elgar Publishing.

Bosche, Peter Van den. (2005).The Law and Policy of the World Trade Organization: Text, Cases and Materials, UK: Cambridge University Press.

Carbaugh, Robert J. (2009).International Economics $12^{\text {th }}$ edition,USA: SouthWestern Cengage Learning.

Charnovitz, Steve. (2001).The WTO and The Rights of Individual, Journal of Intereconomics Vol. March/April, Springer-Verlag.

Charnovitz, Steve. (2001).Economic and Social Actors in the World Trade Organization, ILSA Journal of International and Comparative Law, Spring, 2001, Florida.

Christoph, Antons. (1991).The Development of Intellectual Property Law in Indonesia: From Colonial to National Law , in 22 International Review of Industrial Property and Copyright Law, VCH Verlagsgesellschaft Frankfurt. 
Cooper, Richard N. (1967).National Economic Policy in An Interdependent World Economy, Yale Law Journal June 1967.

Davey, W.J. 'Dispute Settlement Practice Relating to GATT 1994', in The WTO Dispute Settlement System 1995-2003 (Studies in Transnational Economic Law Vol. 18), Ed. by Federic Ortino and Ernst-Urlich Petersmann, Netherlands: Kluwer Law International.

Enforcement of Intellectual Property Rights in Indonesia, Report Prepared By DGIPR Indonesia, available at http://www.ecapproject.org.

European Communities - Regime for the Importation, Sale and Distribution of Bananas - AB-1997-3 - Report of the Appellate Body, (WT/DS27/AB/R), 09-09-1997,

Fidler, David P., Drager, Nick, Correa, Carlos and Aginam, Obijiofor. (2006). 'Making Commitments in Health Services under the GATS: Legal Dimensions, in International Trade in Health Services and The GATS: Current Issues and Debates, Ed. by Chantal Blouin, Nick Drager and Richard Smith, the World Bank.

Hadiz, Vedi R. (2004). 'The failure of State Ideology in Indonesia: the Rise and Demise of Pancasila', in Communitarian Politics in Asia, Ed. by Ben Huat Chua, Routledge - London.

Henkin, Louis.(1995).International Law: Politics and Values, Netherland: Martinus Nijhoff Publisher.

Hill, Hal. (2001).Small and Medium Enterprises in Indonesia: Old Policy Challenges for a New Administration, Asian Survey, Vol. 41, No. 2 (Mar. - Apr., 2001), Published by: University of California Press.

Hoekman, Bernard M.(2002). 'The WTO: Function and Basic Principles', in Development Trade, and the WTO: A Handbook, Ed. by Bernard M. Hoekman, Aaditya Matoo and Philip English, Washington DC: The World Bank.

Jackson, John H.(1997).The World Trading System: Law and Policy of International Economic Law (second Edition), Massachusetts Institutes of Technology - Press.

Jackson, John H. (1995).International Economic Law: Reflections on the "Boilerroom" of International Relations, 10 American University Journal International Law - Washington.

Jackson, John H. (1990).Restructuring the GATT System, Great Britain, UK:Royal Institute of International Affairs.

Jackson, John H. (2006).Sovereignty, the WTO and Changing Fundamentals of International Law, Cambridge University Press.

Kartadjoemena, H.S. (2005). 'Country Report: Indonesia', in The World Trade Organization: Legal, Economic and Political Analysis Volume I, Ed. by Patrick F.J. Macrory, Arthur E. Appleton and Michael G. Plumer, New York:Springer Science + Business Media Inc.

Kartadjoemena, H.S.,(1991),Services Agreement in the Uruguay Round: A Preliminary Assesment of What Could be Expected by SEACEN Countries, Keynote Speech by Ambassador H.S. Kartadjoemena on the Occasion of the SEACEN Central Bank Governors Conference, Jakarta January 30.

Kartadjoemena, H.S. 'Indonesia's Trade Policy: Problems and Options', Selected Key Policy Issues in the Indonesian Economy, Ed. by H.S. Kartadjoemena, Springer - Verlag. 
Kohona, Palitha T.B.(1985), The Regulation International Economic Relations through Law, Netherlands:Martinus Nijhoff Publisher.

Kong, Qinjiang. (2002).China and the World Trade Organization: a Legal Perspective, UK: World Scientific Publishing.

Kunig, Philip, Lau, Niels and Meng, Werner. (1993).International Economic Law : Basic Documents, Berlin: Walter de Gruyter \& Co.

Lowenfeld, Andreas F. (2008).International Economic Law, Second Edition, in International Economic Law Series, UK: Oxford - University Press.

Love, Patrick and Lattimore, Ralph. (2009).International Trade: Free, Fair and Open?, OECD INSIGHTS.

MacDonald, Kate, and Woolcock, Stephen. (2007). 'Non-State Actors in Economic Diplomacy, in The New Economic Diplomacy : Decision Making and Negotiation in International economic Relations (Second Edition), Ed. by Nicholas Bayne and Stephen Woolcock (eds.),UK: Ashgate Publishing Co.

Makarczyk, Jerzy. (1988).Principles of a New International Economic Order: A Study of International Law in the Making, The Netherlands: Martinus Nijhoff Publisher.

Marsh, S.B. and Soulsby, J. (2002).Business Law: Eight Edition, Nelson Thomas Ltd - UK.

Naverson, Jan, “Democracy and Economic Rights”, in Ellen Frankel Paul, Fred D. Miller Jr.And Jeffrey Paul. (eds.)(1992).Economic Rights, USA: Cambridge University Press \& Social Philosophy and Policy Foundation.

North, Douglass and Weingast, Barry. (1989). 'Constitution and Commitment: the Evolution of Institution Governing Public Choice in Seventeenth Century England', 4 Journal of Economic History 49, Cambridge University Press.

OECD. (2001). Trade in Services: Negotiating Issues and Approaches, OECD Publications Services.

Ostrihansky, R. (1991).Settlement of Interstate Trade Disputes - The Role of Law and Legal Procedures, in Netherland Yearbook of International Law 1991, vol. XXII, The Hague.

Owen, Darrel E., Sulaiman, Idris F., Baldia, Sonia and Mintz, Steven P., (2001), Indonesia-Information and Communications Technologies (ICT) Assessment: Technical Report of January 16- February 5, USAID/ECG, Jakarta Indonesia.

Petersmann, E.U. (2005). “Bridging Foundations - Human Rights and International Trade Law: Defining and Connecting the Two Fields", Human Right and International Trade, Ed. by Thomas Cottier, Joost Pauwelyn and Elisabeth Burgi, Oxford University Press - UK.

Petersmann, E.U. (2000). "Judicial Protection of Economic Freedom in National and International Law: Time for Bringing Rights Home”, in Judicial Review in International

Perspective (Liber Amicorum, in Honour of Lord Slynn of Hadley), Ed. By Mads Andenas and Duncan Fairgrieve, Netherland: Kluwer Law International.

Petersmann, E.U. (2008). 'Constitutionalism and WTO Law: From a State Centered Approach Towards a Human Rights Approach in International Economic Law', in The Political Economy of International Trade Law (Essays in Honor of Robert E. Hudec), Ed. by Daniel L. M. Kennedy and James D. Southwick, UK: Cambridge University Press. 
Qureshi, Asif H. (2006).Interpreting WTO Agreements: Problems and Perspective, Cambridge University Press.

Report of State Ministry of Co-operatives and Small/Medium Enterprises, (2001), Co-operative and Small/Medium Enterprises Development in Indonesia, 3 Journal of Economic Cooperation no. 22.

Rickettss, Martin. (2006). "Economic Regulations: Principles, History and Methods", in International Handbook on Economic Regulation, Ed. by Michael Crew and David Parker (eds), UK: Edward Elgar Publishing.

Sanson, Michelle. (2002).Essential International Trade Law, Australia: Cavendish Publishing.

Schaffer, Gregory. (2007). 'Public and Private Partnerships in WTO Dispute Settlement: the US and EU Experience', in The WTO in the Twenty-First Century: Dispute Settlement, Negotiations and Regionalism in Asia, Ed. by Yasuhei Taniguchi, Alan Yanovich and Jan Bohanes, UK: Cambridge University Press.

Shell, G. Richard. (1995).Trade Legalism and International Relations Theory: An Analysis of the World Trade Organization, 44 DUKE Law Journal.

Strange, Susan, (1992), States, Firms, and Diplomacy, International Affairs, Vol. 68, no.1, London.

Stoll, Peter-Tobias and Schofkopf, Franck. (2006).WTO, World Economic Order, World Trade Law, Netherlands: Martinus Nijhoff Publisher.

Sykes, Alan 0.(2005). 'International Trade and Human Rights: An Economic Perspective', in International Trade and Human Rights: Foundations and Conceptual Issues, Ed. by Frederick M. Abbott, Christine BreiningKaufmann, and Thomas Cottier, World Trade Forum, Vol.5, University of Michigan Press - Ann Arbor, Chapter 4.

Theemat, Pieter Verloren. (1981). The Changing Structure of International Economic Law, Netherland:Martinus Nijhoff Publisher.

The Circuit Court of the United States for the Eastern District of Pennsylvania - In Equity, 'in the case of Laura Keene vs. Wheatley \& Clarke', collected by Asa I. Fish and Henry Wharton (eds), (1861), The American Law Register Vol. IX, D.B. Canfield \& Co. Goldsmiths Hall, US: Library Street.

The WTO Data, Indonesia, available at http://stat.wto.org/CountryProfile/ WSDBCountryPFView.aspx?Language $=\mathrm{E} \&$ Country $=$ ID

The ministry of trade provide information and opportunity to request and to comment on drafts laws and legislative for businesses and enterprises, available at http://www.kemendag.go.id/en/perdagangan-kita/

Trachtman, Joel P. (1996).The International Economic Law Revolution, 17 University Pennsylvania Journal International Economic Law.

Tambunan, Tulus. (2009).Facilitating Small and Medium Enterprises in International Trade (Export): The Case of Indonesia, Paper Presented in AsiaPacific Trade Economists' Conference: 'Trade Led Growth in Time of Crisis', UN-ESCAP, 9 November 2009, p. 21-22.

Voitovich, Sergei A. (1995).International Economic Organizations in the International Legal Process, Netherland: Martinus Nijhoff Publishers.

Zamora, Stephen. (1996).Introduction: International Economic Law, University of Pennsylvania Journal of International Economic Law, Spring 1996. 


\section{Legal Documents}

General Agreement on Trade in Services, Article VI available at http://www. wto.org/english/docs_e/legal_e/26-gats.pdf, last visited 12 April 2010.

General Assembly Resolution, A/RES/S-6/3201, Declaration on the Establishment of a New International Economic Order (NIEO), 1 May 1974

GATS Annex on Movement of Natural Persons Supplying services Under the Agreement, available at http://www.wto.org/english/docs_e/ legal_e/26-gats.pdf

Ministerial Decree No. M/11/PR/07/06/2003 available at http://www.legalitas.org/database/puu/2003/kepmenkehM11-2003.pdf

The WTO Annex 1C, Agreement on Trade-Related Aspects of Intellectual Property Rights, available at http://www.wto.org/english/docs_e/ legal_e/27-trips.pdf, last visited 12 April 2010.

The United States of Uruguay Round Agreements Act, P.L. 103-465, 19 U.S.C.\$§ 3501.

Undang-undang No. 25 tahun 2007 tentang Penanaman Modal, see also Nusantara Network, Indonesia's Investment Law 2007, available at: http:// www.fdi.net/documents/WorldBank/databases/indonesi/indonesia_ investment_law_07.pdf

\section{Website}

"Saling Tuding di Balik Investasi”, available at http://www.media-indonesia. com

“Dua Partai Politik Menolak Undang-undang” available at: www//tempointeractive.com 